\title{
Penerapan Unmanned Aerial Vehicle (UAV) untuk Pengukuran Kuat Sinyal (Drive Test) pada Jaringan 4G LTE
}

\author{
Faisal Ahmad Ilham Nuari, Uke Kurniawan Usman*, AT Hanuranto \\ Fakultas Teknik Elektro, Universitas Telkom, Bandung \\ * email: ukeusman@telkomuniversity.ac.id
}

\begin{abstract}
The work to get data directly from the field for optimizing a network is called drive test. The implementation of drive test by directly down to the field has several obstacles, such as the condition of the terrain is insufficient and risky to be passed by car. Barriers such as traffic congestion, risky environmental conditions and narrow road areas between buildings makes the implementation of drive test by using unmanned aerial vehicle (UAV) or known by drone. In this research, drive test is carried out on 4G LTE Network and uses an Android smartphone that has the G-NetTrack application installed. The Data parameters of the drive Test and QoS are searched. There are Reference Signal Receive Power (RSRP), Reference Signal Receiving Quality (RSRQ), Signal to Noise Ratio (SNR), delay and throughput. This research compares two methods, which are drive test with normal condition and drive test by using a UAV. The result of the drive test with normal condition is obtained an average value of RSRP -90.32 dBm, RSRQ -9.58 dB and SNR $3.99 \mathrm{~dB}$. Whereas in the drive test by using $U A V$ is obtained an average value RSRP -90.8 dBm, RSRQ $9.32 \mathrm{~dB}$ and $S N R$ 4.77 $d B$. The results of this research showed that all parameters in comparison of both methods has meet the standard of Key Performance Indicator (KPI) with small value difference because drive test by using UAV is equals with normal drive test that is to know the real condition of obstacle in field.
\end{abstract}

\section{Keywords: Drive Test, Unmanned Aerial Vehicle, RSRP, RSRQ, SNR}

\section{Pendahuluan}

Mengetahui kondisi di lapangan secara langsung merupakan hal penting dalam tahapan pengembangan dan optimasi jaringan. Drive test dapat mengambil data secara real pada suatu wilayah untuk memastikan dan mengukur kualitas sinyal yang dipancarkan oleh Base Transceiver Station (BTS) yang mencakup availability, capacity dan quality sehingga dapat ditingkatkan untuk performasi layanan yang diberikan [1]. Data yang diambil dari drive test adalah jaringan $4 G L T E$. Pada Jaringan $4 G L T E$ nilai yang dianalisis adalah kekuatan sinyal (RSRP), kualitas sinyal (RSRQ), Signal to Noise Ratio (SNR), Throughput dan Delay [2-8].

Dalam perkembangan teknologi telekomunikasi nirkabel saat ini, usaha untuk mendapatkan data secara update dan efisien sangatlah penting. Penelitian untuk drive test pada penelitian ini dilakukan dengan cara membandingkan drive test normal pada umumnya dengan drive test menggunakan UAV di jalur mapping yang sudah ditentukan [7, 9]. Penelitian ini dilakukan untuk memperoleh nilai parameter yang diujikan dari pengimplementasian drive test dengan teknologi UAV dan diupload ke database. Usaha ini digunakan untuk mendapatkan hasil yang efisien dan lebih maksimal, sehingga membantu pekerjaan drive test di lapangan [6-10]. 


\section{Metodologi Perancangan}

\subsection{Kondisi Existing}

Penelitian drive test untuk jaringan 4G LTE dilakukan di kawasan Telkom University. Jalur drive test dimulai dari gate mobil ketiga, masuk ke arah Gedung Rektorat. Kemudian belok ke kiri mengitari fakultas teknik dan gedung GSG. Titik akhirnya sama dengan titik mulainya, yaitu di depan Gedung Rektorat. Rute drive test yang dilakukan dapat dilihat di Gambar 1.

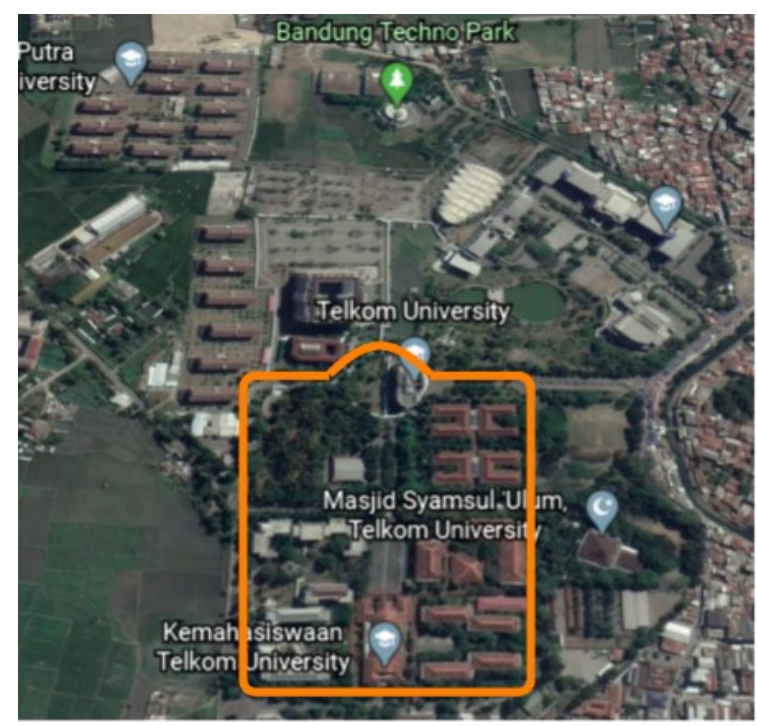

Gambar 1. Rute pelaksanaan drive test

\subsection{Skema Penelitian}

Drive test dilakukan dengan dua metode yaitu drive test normal dengan berjalan kaki atau walking test dan drive test menggunakan UAV. Drive test menggunakan UAV dilakukan dengan menempelkan smartphone pada UAV. Data yang diperoleh dari drive test kemudian dianalisis dan di-upload ke database melalui website. Alur penelitian dapat dilihat pada Gambar 2.

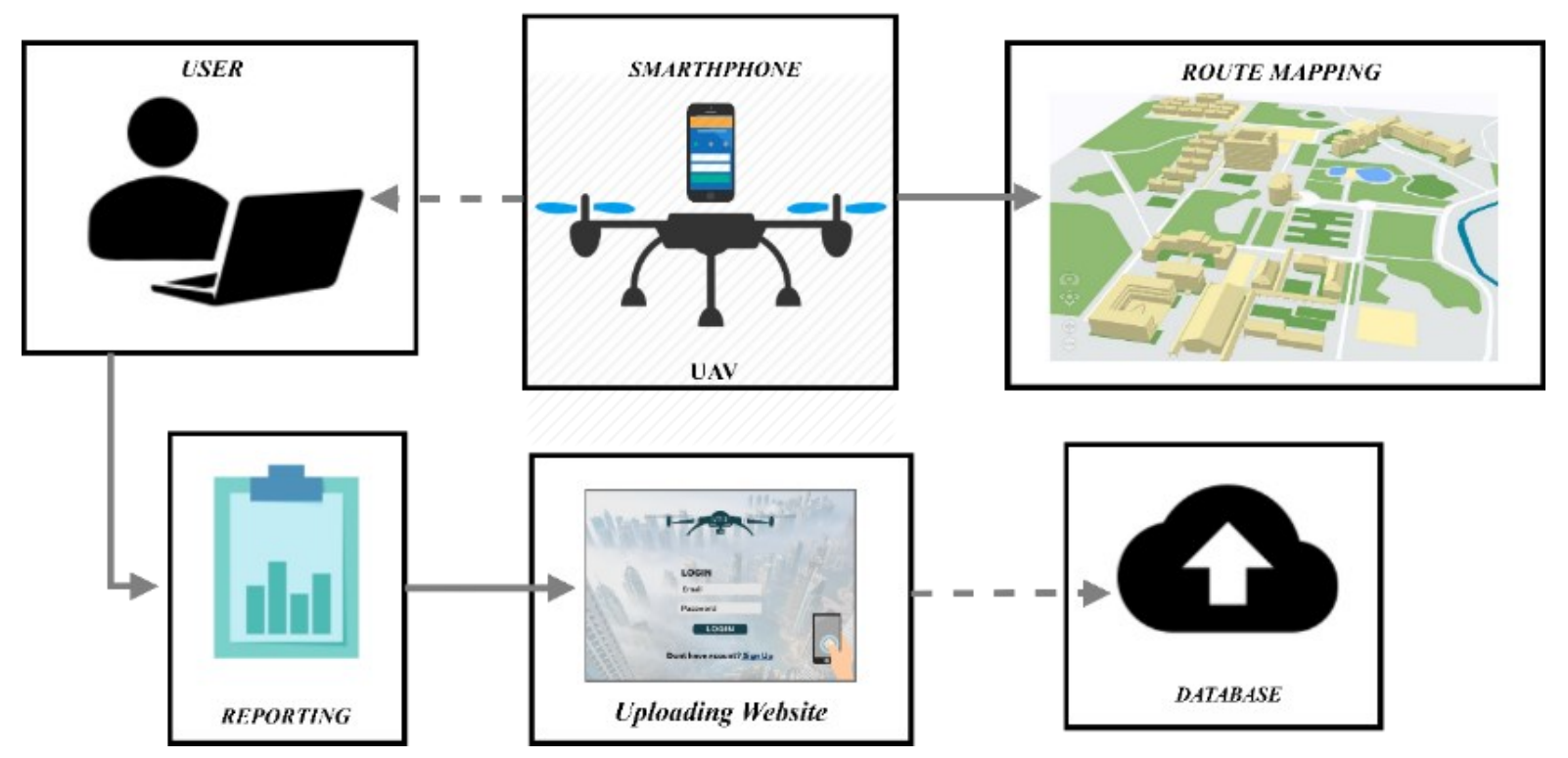

Gambar 2. Alur kerja penelitian 


\subsection{Diagram Alir}

Drive test dilakukan menggunakan smartphone yang sudah terinstal aplikasi GNetTrack dan smartphone tersebut dibawa oleh UAV. Metode drive test yang dilakukan sama dengan drive test normal, yaitu merekam data langsung di lapangan dan berpindah dari satu titik ke titik yang lainnya berdasarkan rute yang ditentukan. Smarthphone yang dibawa oleh UAV dimonitor dan dikendalikan melalui laptop dengan aplikasi TeamViewer. Nilai dari drive test yang dianalisis adalah nilai untuk mengukur kualitas pancaran sinyal oleh BTS yang mencakup availability, capacity dan quality. Nilai parameter yang dibutuhkan yaitu RSRP, RSRQ, SNR dan parameter QOS Delay, Throughput. Diagram alir penelitian dapat dilihat pada Gambar 3.

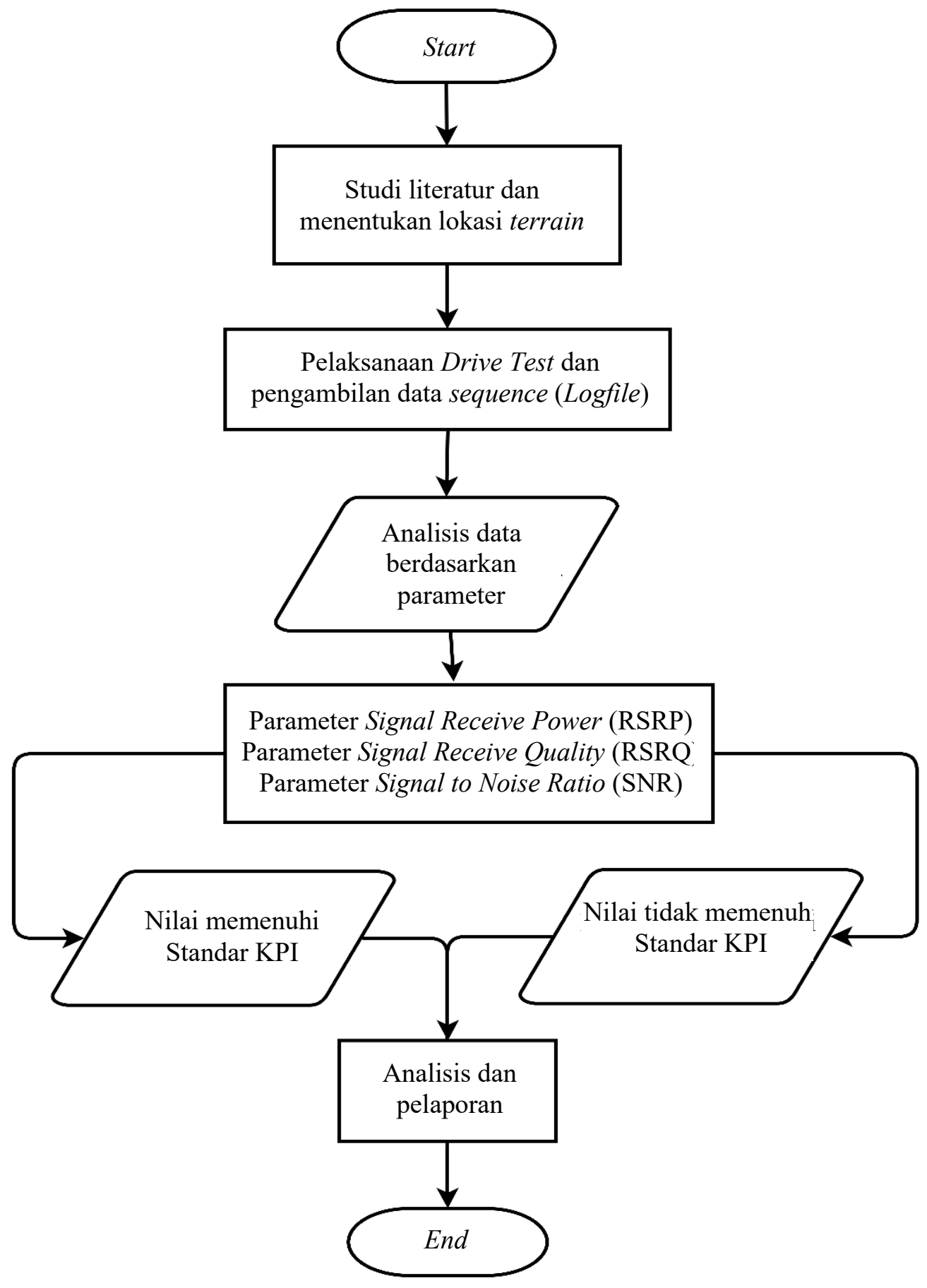

Gambar 3. Diagram alir proses drive test 


\subsection{Spesifikasi Alat}

Adapun spesifikasi alat dapat dilihat pada Tabel 1.

Tabel 1. Spesifikasi Alat

\begin{tabular}{|c|c|c|}
\hline No. & Perangkat & Spesifikasi \\
\hline 1 & Smartphone & Samsung A50 \\
\hline 2 & Laptop & Asus A451L \\
\hline 3 & Software Drive Test & G-NetTrack v17.5 \\
\hline 4 & Flight Controller UAV & Flight controller pixhawk 2.1 cube \\
\hline 5 & Remote UAV & Remote taranis x9r \\
\hline 6 & Reciver Signal UAV & Receiver frsky x9r \\
\hline 7 & Komponen Penggerak UAV & $\begin{array}{c}4 \text { motor t-motor mn } 4014-9400 \mathrm{kv} \\
4 \text { esc t-motor } 40 \mathrm{a} \\
4 \text { propeller } 16 * 6.5 \\
\end{array}$ \\
\hline 8 & Baterai UAV & $\begin{array}{c}\text { Baterai lipo 6s } 10000 \& 8000 \mathrm{mAh} \\
\text { (optional) }\end{array}$ \\
\hline 9 & Kartu SIM Provider & Provider XL Axiata support 4G LTE \\
\hline
\end{tabular}

\subsection{Parameter Pengukuran}

\subsubsection{Reference Signal Receive Power (RSRP)}

Reference Signal Receive Power (RSRP) adalah power dari sinyal yang diterima oleh User Equipment. Semakin jauh jarak antara site dengan user, maka semakin kecil RSRP yang diterima oleh user. Parameter RSRP digunakan oleh perangkat untuk menentukan titik handover. Range baik dan buruk RSRP dapat dilihat pada Tabel 2 . Perhitungan RSRP mengikuti Persamaan (1) [3-5].

$$
R S R P(d b m)=R S S I(d b m)-10 \times \log (12 \times N)
$$

Dimana RSSI didapat Persamaan (2).

$$
\operatorname{RSSI}(\mathrm{dbm})=P 1+P 2+P 3
$$

dengan:

RSSI = Indikator kekuatan sinyal/Received Signal Strength Indicator

$\mathrm{N}$ = Jumlah Resource Blok

$\mathrm{P} 2=$ Power noise

$\mathrm{P} 1=$ Power sinyal

P3 = Power interferensi

Tabel 2. KPI Parameter RSRP

\begin{tabular}{c|c|c}
\hline Warna & Kategori & Nilai RSRP $(\mathrm{dBm})$ \\
\hline & Excellent & $\geq-70$ \\
\hline & Very Good & $-70 \mathrm{~s} / \mathrm{d}-80$ \\
\hline & Good & $-80 \mathrm{~s} / \mathrm{d}-90$ \\
\hline & Normal & $-90 \mathrm{~s} / \mathrm{d}-100$ \\
\hline & Bad & $-100 \mathrm{~s} / \mathrm{d}-110$ \\
\hline & Very Bad & $110 \mathrm{~s} / \mathrm{d}-120$ \\
\hline
\end{tabular}




\subsubsection{Reference Signal Receive Quality (RSRQ)}

Reference Signal Receive Quality (RSRQ) adalah rasio antara RSRP dan wideband power. RSRQ merupakan kualitas sinyal yang diterima. RSRQ adalah yang membantu parameter RSRP saat terjadi handover. Parameter RSRQ juga didefinisikan sebagai rasio antara jumlah resource block terhadap rata-rata daya linier yang terima oleh user termasuk daya dari serving cell, noise, dan interferensi[12]. Range KPI nilai RSRQ dari 2 s/d -20 dapat dilihat pada Tabel 3. Perhitungan rumus RSRQ mengikuti Persamaan (3) [3-7].

$$
R S R Q(d b)=\frac{N \times R S S P(d b m)}{R S S I}
$$

dimana:

RSRP $=$ Kuat sinyal yang diterima oleh UE dari eNodeB

RSSI = Indikator kekuatan sinyal

$\mathrm{N} \quad=$ Jumlah Resource Blok

Tabel 3. KPI Parameter RSRQ

\begin{tabular}{c|c|c}
\hline Warna & Kategori & Nilai RSRQ (dB) \\
\hline \multirow{5}{*}{} & Excellent & $\geq 2$ \\
\hline & Very Good & $2 s / d-1$ \\
\hline & Good & $-1 s / d-7$ \\
\hline & Normal & $-7 s / d-10$ \\
\hline & Bad & $-10 s / d-14$ \\
\hline & Very Bad & $-14 s / d-20$ \\
\hline
\end{tabular}

\subsubsection{Signal To Noise Ratio (SNR)}

SNR adalah rasio kualitas antara daya yang diterima dengan rata-rata noise yang mempengaruhi saat pengiriaman atau penerimaan data[12]. Range nilai KPI untuk SNR dari -10 s/d 20 sesuai Tabel 4, dengan perhitungan SNR mengikuti Persamaan (4) [3-7].

$$
\operatorname{SNR}(d b)=\frac{S}{N}
$$

dimana:

$\mathrm{S}=$ Rata-rata kuat sinyal.

$\mathrm{I}=$ Power rata-rata interferensi.

$\mathrm{N}=$ Power Noise.

Tabel 4. KPI Parameter SNR

\begin{tabular}{c|c|c}
\hline Warna & Kategori & Nilai SNR $(\mathrm{dB})$ \\
\hline & Excellent & $\geq 20$ \\
\hline & Very Good & $15 \mathrm{~s} / \mathrm{d} 10$ \\
\hline & Good & $10 \mathrm{~s} / \mathrm{d} 5$ \\
\hline & Normal & $5 \mathrm{~s} / \mathrm{d} 0$ \\
\hline & Bad & $0 \mathrm{~s} / \mathrm{d}-5$ \\
\hline & Very Bad & $<-10$ \\
\hline
\end{tabular}

\subsection{Implementasi UAV}

Skenario pertama drive test menggunakan UAV yang dilakukan yaitu menggunakan remot manual sebagai controller untuk menghindari obstacle yang ada selama melalaui rute yang ditentukan, seperti yang ditampilkan pada Gambar 1. Skenario kedua drive test menggunakan UAV yang diintegrasi dengan modul auto pilot yang bernama ArduPilot 
sehingga dapat berjalan secara otomatis untuk menuju titik koordinat yang sudah ditentukan dalam mapping GPS yang dapat dikonfigurasi pada software Ardupilot.

\subsection{Website}

Website dibuat untuk menyimpan data ke database dan diteruskan ke aplikasi android untuk menampilkan hasil drive test. Website ini dapat diakses oleh beberapa pengguna atau multi user lewat menu sign up dan login.

\section{Pembahasan}

\subsection{Analisis Drive Test Normal}

Setelah melakukan pengambilan data dengan berjalan kaki pada rute Telkom University dan menggunakan aplikasi G-NetTrack, didapatkan empat nilai yaitu: RSRP, RSRQ, SNR dan Delay.

\subsubsection{Hasil Nilai Parameter RSRP}

Berdasarkan drive test yang telah dilakukan, diperoleh hasil sebanyak 640 data sequence dari script yang dijalankan pada aplikasi G-NetTrack. Nilai rata-rata dari parameter RSRP diperoleh $-90.32 \mathrm{dBm}$. Mengacu pada Tabel 2 tentang standar Key Performance Indicator (KPI), maka daya sinyal yang diterima, tergolong dalam kategori normal. Perolehan nilai RSRP dapat dilihat pada Gambar 4.

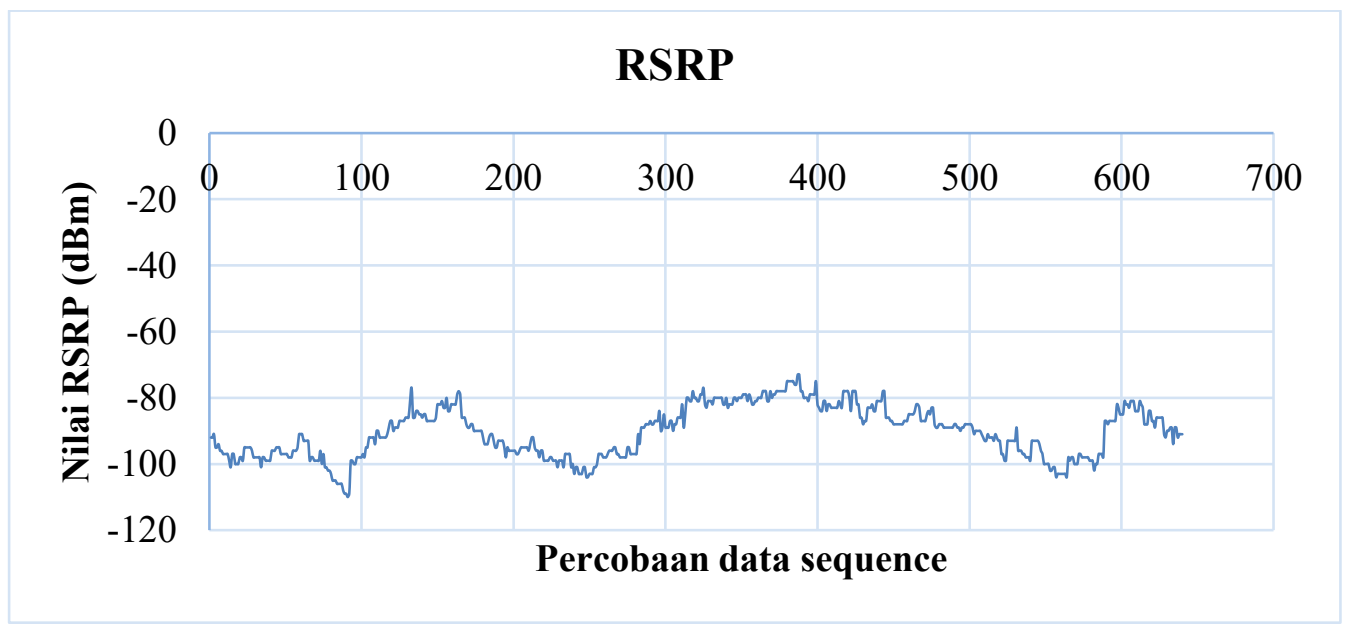

Gambar 4. Perolehan nilai RSRP dari drive test normal

Berdasarkan pengujian diperoleh informasi nilai pada setiap titik yang berada di dalam peta mapping drive test yang dilakukan. Warna titik pada mapping mengindikasikan kategori RSRP dari Very Good sampai dengan Bad. Warna kuning menandakan nilai RSRP pada titik tersebut dikategorikan Very Good karena minimnya obstacle yang ada sehingga dapat secara langsung line of sight dengan BTS. Sedangkan warna biru tua dikategorikan Bad. Berdasarkan data yang sudah diperoleh pada Gambar 4, terjadi penurunan nilai RSRP pada beberapa titik. Titik yang mengalami penurunan dapat dilihat pada Gambar 5 dengan warna biru tua yang masuk kedalam kategori $\mathrm{Bad}$. Penurunan tersebut disebabkan adanya obstacle yang menyebabkan komunikasi menjadi tidak bersifat line of sight sehingga nilai RSRP yang didapatkan tidak maksimal. 


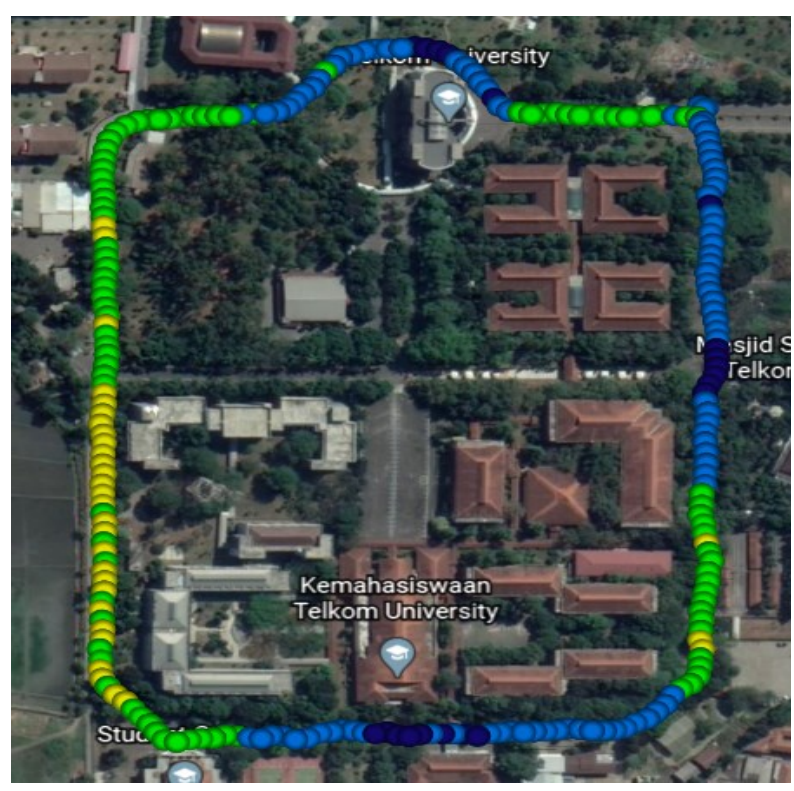

Gambar 5. Penyebaran titik sequence dalam rute drive test normal

\subsubsection{Hasil Nilai Parameter RSRQ}

Pada drive test yang dilakukan, nilai rata-rata RSRQ yang diperoleh yaitu $-9.58 \mathrm{~dB}$ dan menurut standar KPI tergolong normal. Perolehan nilai RSRQ ditampilkan pada Gambar 6.

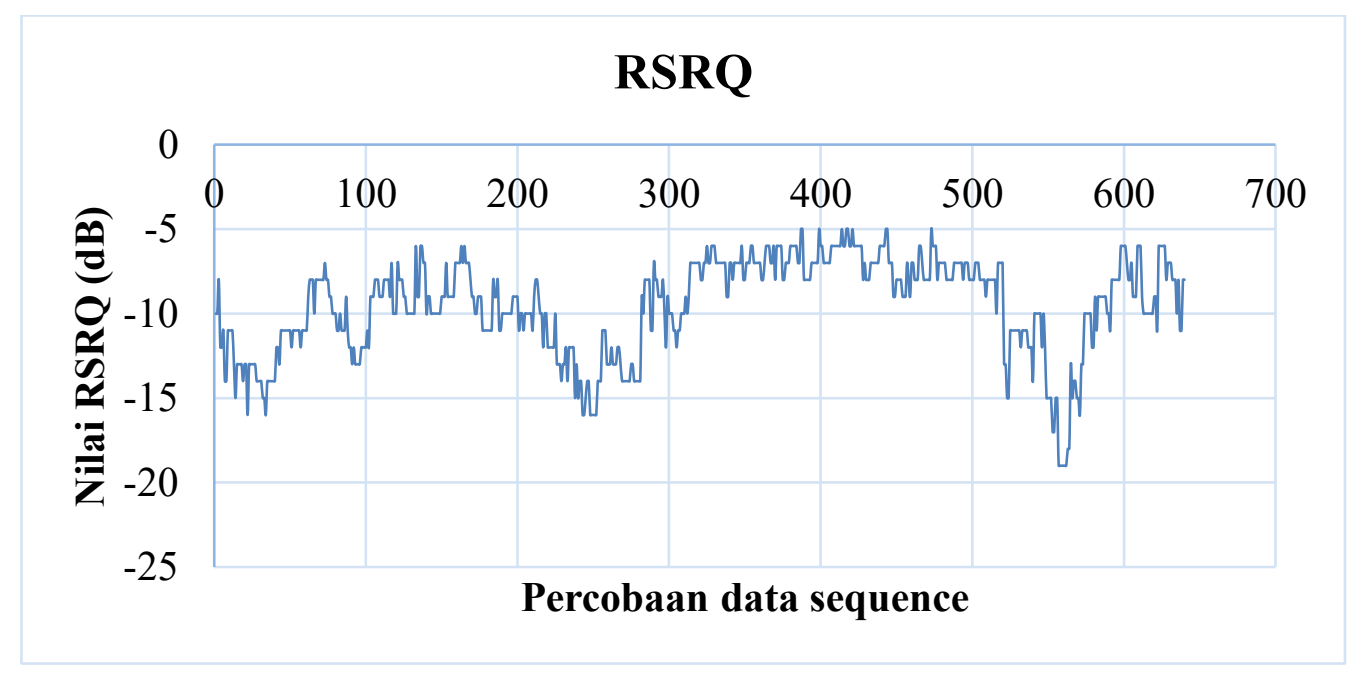

Gambar 6. Perolehan nilai RSRQ dari drive test normal

Sama halnya dengan parameter RSRP, penurunan nilai yang ditunjukkan pada Gambar 6 terjadi akibat adanya obstacle di lintasan komunikasi BTS dengan UE, sehingga tidak memenuhi LOS dan menyebabkan penurunan nilai RSRQ. 


\subsubsection{Hasil Nilai Parameter SNR}

Melalui drive test yang dilakukan, perolehan nilai SNR sebagaimana yang ditampilkan pada Gambar 7, memiliki rata-rata sebesar 3.99 dB. Menurut Tabel 4, nilai ini tergolong dalam kategori normal.

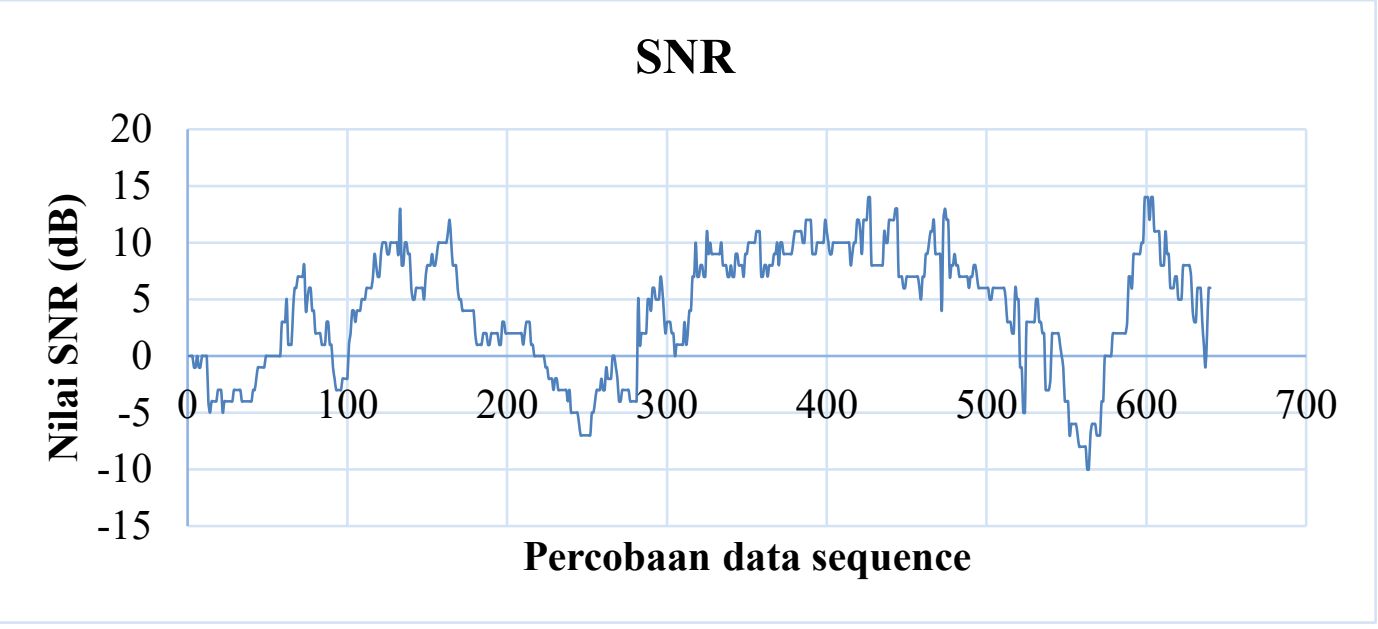

Gambar 7. Perolehan nilai SNR dari drive test normal

Penurunan nilai SNR yang ditampilkan pada Gambar 7 terjadi karena keberadaan obstacle pada lintasan komunikasi BTS dan UE.

\subsection{Analisis Drive Test menggunakan UAV}

Hasil pengambilan data drive test dengan mengimplementasikan UAV yang dirutekan, sama dengan pengambilan data dengan drive test normal. Drive test dilakukan dengan cara UAV membawa smartphone untuk menghidari beberapa obstacle yang ada. Didapatkan empat parameter pengujian yaitu RSRP, RSRQ, SNR dan Delay.

\subsubsection{Hasil Nilai Parameter RSRP}

Proses pengambilan data dengan drive test yang menggunakan UAV memperoleh 655 data sequence. Perolehan nilai RSRP dapat dilihat pada Gambar 8 dengan nilai rata-rata sebesar -90.8 dBm. Menurut standar KPI, nilai tersebut tergolong kategori normal.

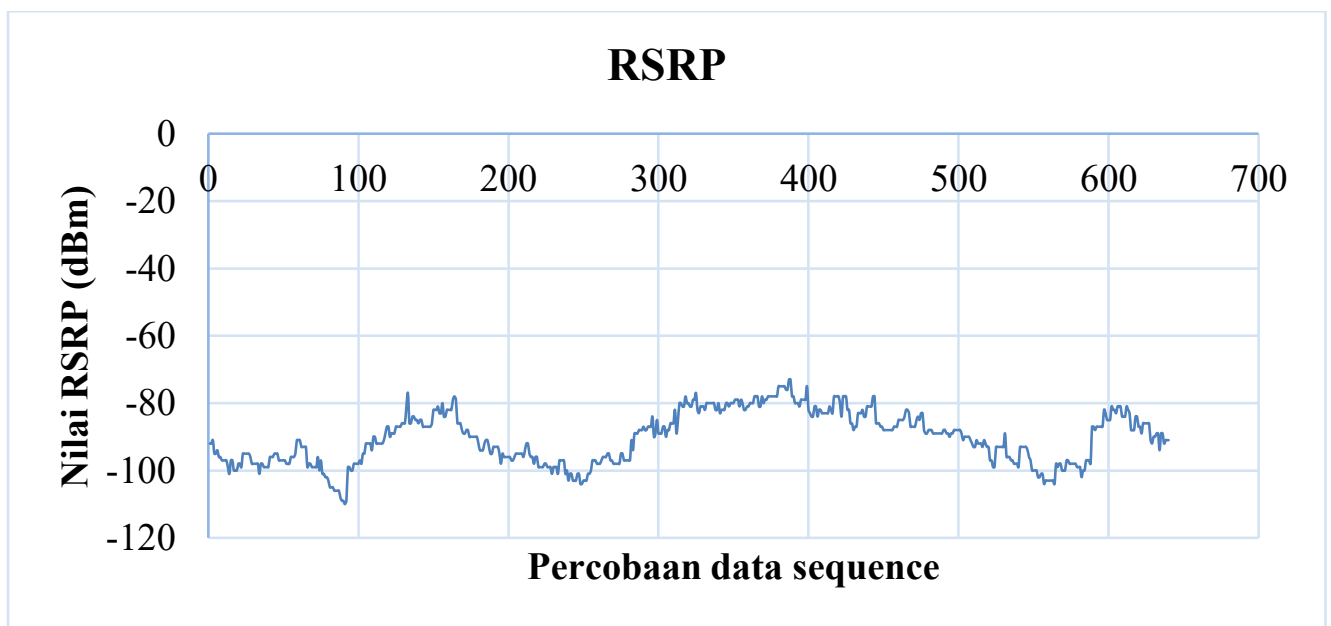

Gambar 8. Perolehan nilai RSRP dari drive test dengan UAV

Warna titik yang ada pada Gambar 9 menandakan beberapa variasi kategori RSRP dari Excellent sampai Bad. Warna orange hingga biru muda termasuk ke kategori yang dapat 
diterima menurut KPI. Titik yang dikategorikan bad tersebut disebabkan adanya obstacle yang menyebabkan komunikasi menjadi tidak bersifat line of sight.

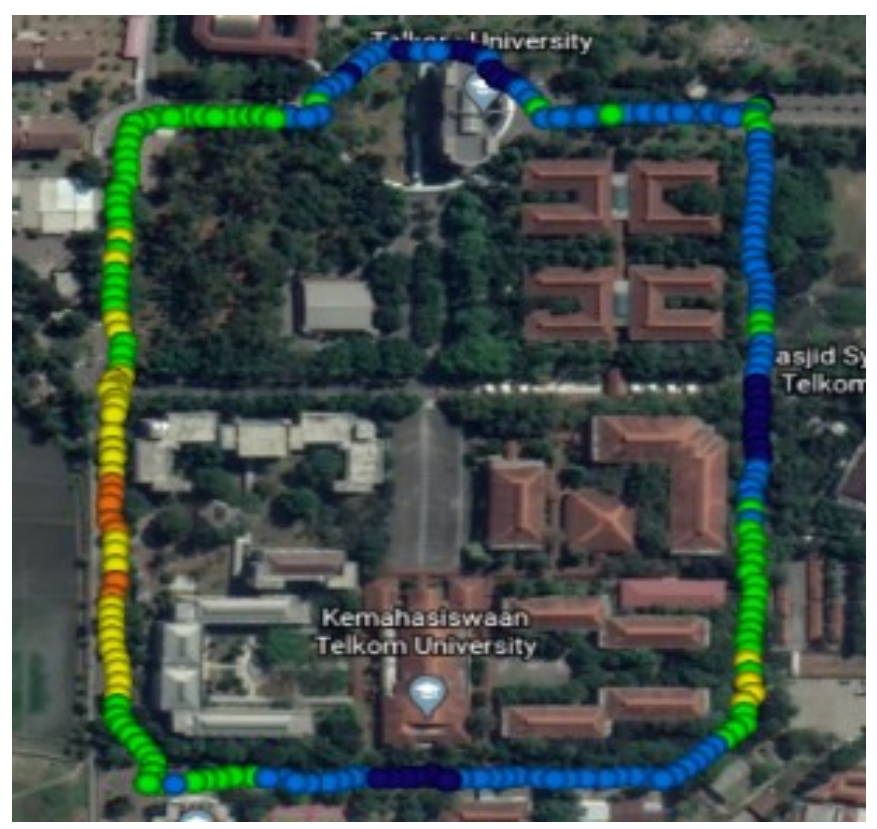

Gambar 9. Penyebaran titik sequence dalam drive test dengan UAV

\subsubsection{Hasil Nilai Parameter RSRQ}

Pada Drive test yang dilakukan menggunakan UAV untuk membawa smartphone melewati rute yang sama dengan Drive test normal, didapatkan nilai parameter RSRQ seperti yang terlihat pada Gambar 10. Nilai rata-rata RSRQ yang diperoleh yaitu $-9.32 \mathrm{~dB}$ dimana menurut standar KPI, tergolong kategori normal.

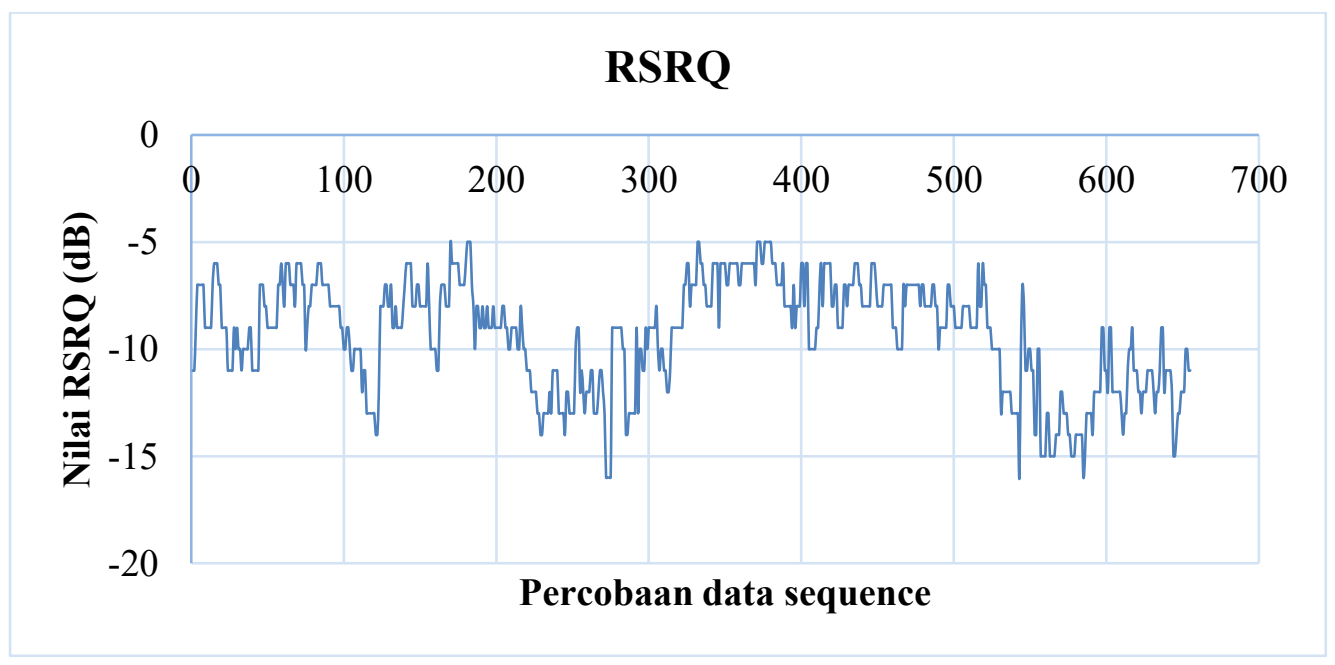

Gambar 10. Perolehan nilai RSRQ dari drive test dengan UAV

Penurunan yang terjadi pada nilai RSRQ seperti yang ditampilkan pada Gambar 11 terjadi karena adanya noise dan interferensi saat drive test sedang berlangsung. 


\subsubsection{Hasil Nilai Parameter SNR}

Hasil nilai parameter SNR yang didapatkan dari drive test menggunakan UAV di rute yang sama dengan drive test normal dapat dilihat pada Gambar 11, dengan nilai ratarata sebesar $4.77 \mathrm{~dB}$, sehingga menurut standar KPI termasuk kedalam kategori normal.

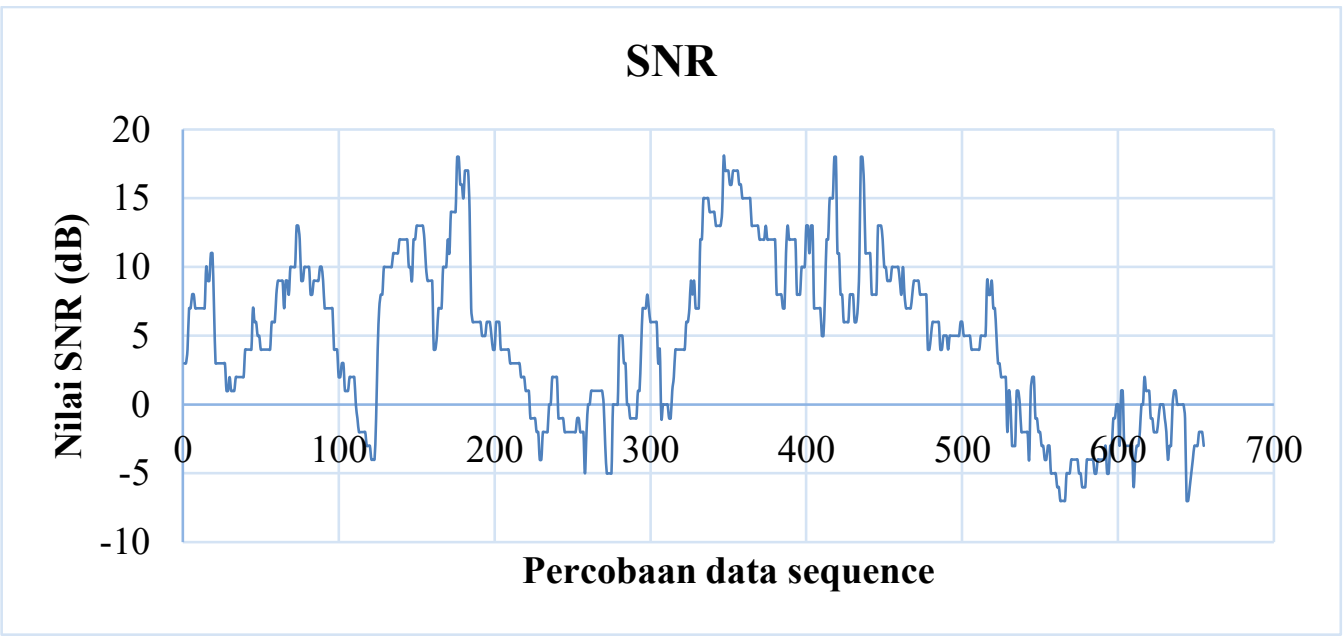

Gambar 11. Perolehan nilai SNR dari drive test dengan UAV

Melalui drive test yang dilakukan, dapat diperoleh informasi mengenai indikator dengan warna merah sampai dengan biru muda yang menandakan terdapat nilai dengan kategori very good sampai dengan very bad. Sama seperti parameter lainnya, keberadaan obstacle juga berdampak pada parameter SNR.

\subsection{Analisis Perbandingan Kedua Metode Drive Test}

\subsubsection{Perbandingan Nilai RSRP}

Nilai RSRP dari kedua drive test tidak jauh berbeda. Pada beberapa titik nilai RSRP mengalami penurunan yang terjadi akibat adanya obstacle pada lintasan komunikasi, sehingga mempengaruhi nilai yang diperoleh. Perbandingan nilai RSRP dari kedua metode drive test dapat dilihat pada Tabel 5.

Tabel 5. Perbandingan nilai RSRP dari kedua metode drive test

\begin{tabular}{c|c|c|c|c|c}
\hline \multirow{2}{*}{ Warna } & \multirow{2}{*}{ Range } & \multicolumn{3}{|c}{ Jumlah dan Presentase Data Nilai RSRP } \\
\cline { 3 - 6 } & $\geq-70$ & 0 & 0 & 15 & $2.29 \%$ \\
\hline & $-70 \mathrm{~s} / \mathrm{d}-80$ & 76 & $11.88 \%$ & 77 & $11.75 \%$ \\
\hline & $-80 \mathrm{~s} / \mathrm{d}-90$ & 257 & $40.16 \%$ & 188 & $28.70 \%$ \\
\hline & $-90 \mathrm{~s} / \mathrm{d}-100$ & 257 & $40.15 \%$ & 299 & $45.65 \%$ \\
\hline & $-100 \mathrm{~s} / \mathrm{d}-110$ & 50 & $7.81 \%$ & 75 & $11.45 \%$ \\
\hline & $110 \mathrm{~s} / \mathrm{d}-120$ & 0 & 0 & 1 & $0.15 \%$ \\
\hline Jumlah & & 640 & $100 \%$ & 655 & $100 \%$ \\
\hline
\end{tabular}

Berdasarkan Tabel 5, nilai RSRP pada drive test normal adalah $-90.32 \mathrm{dBm}$, lebih besar $0,48 \mathrm{dBm}$ dibanding nilai RSRP pada drive test menggunakan UAV yang nilainya sebesar $-90.8 \mathrm{dBm}$. 


\subsubsection{Perbandingan Nilai RSRQ}

Nilai RSRQ yang didapat dari kedua metode drive test tidak jauh berbeda. Pada beberapa titik nilai RSRQ mengalami penurunan, hal tesebut dikarenakan adanya noise dan juga interferensi sehingga mempengaruhi hasil nilai yang didapatkan. Perbandingan kedua metode drive test dalam hal nilai RSRQ dapat dilihat pada Tabel 6.

Tabel 6. Perbandingan nilai RSRQ kedua metode drive test

\begin{tabular}{c|c|c|c|c|c}
\hline \multirow{2}{*}{ Warna } & \multirow{2}{*}{ Range } & \multicolumn{4}{|c}{ Jumlah Data Nilai RSRQ } \\
\cline { 3 - 6 } & & \multicolumn{2}{|c|}{ Drive Test Normal } & \multicolumn{2}{c}{ Drive Test UAV } \\
\hline & $\geq 2$ & 0 & 0 & 0 & 0 \\
\hline & $2 \mathrm{~s} / \mathrm{d}-1$ & 0 & 0 & 0 & 0 \\
\hline & $-1 \mathrm{~s} / \mathrm{d}-7$ & 181 & $28.28 \%$ & 187 & $28.55 \%$ \\
\hline & $-7 \mathrm{~s} / \mathrm{d}-10$ & 245 & $38.28 \%$ & 264 & $40.30 \%$ \\
\hline & $-10 \mathrm{~s} / \mathrm{d}-14$ & 177 & $27.65 \%$ & 184 & $28.09 \%$ \\
\hline & $-14 \mathrm{~s} / \mathrm{d}-20$ & 37 & $5.78 \%$ & 20 & $3.05 \%$ \\
\hline & Jumlah & 640 & $100 \%$ & 655 & $100 \%$ \\
\hline
\end{tabular}

Berdasarkan Tabel 6, nilai RSRQ pada drive test nomal adalah $-9.58 \mathrm{~dB}$, sedangkan nilai drive test menggunakan UAV adalah $-9.32 \mathrm{~dB}$. Terdapat selisih $0.26 \mathrm{~dB}$ dengan nilai lebih besar pada metode drive test menggunakan UAV.

\subsubsection{Perbandingan Nilai SNR}

Nilai SNR yang diperoleh dari kedua metode drive test tidak jauh berbeda. Pada beberapa titik nilai SNR mengalami penurunan, hal tesebut disebabkan karenan adanya obstacle pada lintasan komunikasi sehingga berdampak negative terhadap nilai SNR yang didapatkan. Perbandingan nilai SNR dari kedua metode dapat dilihat pada Tabel 7.

Tabel 7. Perbandingan nilai SNR dari kedua metode drive test

\begin{tabular}{c|c|c|c|c|c}
\hline \multirow{2}{*}{ Warna } & \multirow{2}{*}{ Range } & \multicolumn{4}{|c}{ Jumlah Data Nilai SNR } \\
\cline { 3 - 6 } & & Drive Test Normal & \multicolumn{2}{c}{ Drive Test UAV } \\
\hline & $\geq 20$ & 0 & 0 & 24 & $3.66 \%$ \\
\hline & $15 \mathrm{~s} / \mathrm{d} 10$ & 51 & $7.97 \%$ & 95 & $14.50 \%$ \\
\hline & $10 \mathrm{~s} / \mathrm{d} 5$ & 252 & $39.37 \%$ & 186 & $28.40 \%$ \\
\hline & $5 \mathrm{~s} / \mathrm{d} 0$ & 162 & $25.31 \%$ & 164 & $25.09 \%$ \\
\hline & $0 \mathrm{~s} / \mathrm{d}-5$ & 136 & $21.25 \%$ & 154 & $23.51 \%$ \\
\hline & $<-5$ & 39 & $6.09 \%$ & 32 & $4.88 \%$ \\
\hline
\end{tabular}

Nilai SNR yang diperoleh dari drive test normal adalah $3.99 \mathrm{~dB}$, lebih kecil 0,78 dB dibanding nilai pada drive test menggunakan UAV yang mencapai $4.77 \mathrm{~dB}$.

\subsubsection{Perbandingan Nilai Delay}

Pengukuran nilai delay dilakukan dengan cara menghitung lamanya waktu tempuh data, dimulai saat melakukan ping ke alamat yang dituju oleh script data sequence. Nilai rata- rata delay yang didapatkan pada drive test normal adalah $169.2 \mathrm{~ms}$, sedangkan pada drive test dengan UAV, nilainya sebesar 169,31. 


\subsubsection{Perbandingan Nilai Throughput}

Permasalahan throughput yang nilainya kurang bagus dapat terjadi karenan kualitas dan daya sinyal yang diterima oleh user buruk dalam jaringan tersebut. Penyebab lainnya adalah adalah kapasitas jaringan yang tidak dapat mencukupi kebutuhan user. Nilai rata-rata throughput yang diperoleh saat melakukan drive test normal adalah 2,1 Mbps, sedangkan untuk drive test dengan UAV, nilai throughput yang diperoleh sebesar 1,9 Mbps. Perolehan nilai throughput dari kedua metode tersebut dalam kapasitas jaringan yang disediakan masih jauh dari standar KPI yang ada, dimana nilai yang memenuhi standar KPI adalah rata-rata throughput harus lebih besar atau sama dengan $20 \mathrm{Mbps}$.

\section{Kesimpulan}

Dari analisis yang telah dipaparkan di muka, dapat disimpulkan bahwa daya sinyal dan kualitas sinyal yang dipancarkan dari site ke user tercukupi. Drive test yang dilakukan pada area Telkom University dengan ketiga parameter yang diukur pada beberapa titik yang sama memiliki nilai yang buruk. Nilai yang buruk tersebut dikarenakan adanya obstacle seperti Gedung Rektorat, Masjid Syamsul Ulum dan Gedung GSG yang menyebabkan komunikasi User dan BTS tidak bersifat line of sight sehingga terjadi noise dan interferensi. Nilai parameter yang didapatkan pada penelitian masing-masing parameter memiliki selisih nilai yaitu: kekuatan sinyal (RSRP) lebih besar $0,5 \mathrm{dBm}$ pada metode drive test UAV, sedangkan nilai kualitas sinyal (RSRQ) lebih besar $0,26 \mathrm{dBm}$ pada drive test normal dan nilai rasio noise sinyal (SNR) lebih besar $0,78 \mathrm{~dB}$ pada drive test normal. Selain itu, nilai QoS delay yang didapatkan yaitu 169,2 ms dan 169,31 ms sehingga termasuk kategori normal. Hal ini berhubungan dengan nilai SNR yang dikategorikan normal, sedangkan nilai throughput yang didapatkan adalah 2,1 Mbps dan 1,9 Mbps, mempunyai nilai yang jauh dari standar KPI yaitu $20 \mathrm{Mbps}$. Dapat disimpulkan bahwa hasil drive test normal dan drive test menggunakan UAV memiliki perbedaan nilai yang kecil. Hal ini dikarenakan drive test yang menggunakan UAV dilakukan dengan metode yang sama dengan drive test normal untuk mengetahui kondisi secara real dari obstacle yang ada di lapangan.

\section{Daftar Pustaka}

[1] Hikmaturokhman, A., Wardhana, L., Aginsa, B. F., Dewantoro, A., Rian, M. F., Harto, I., \& Mahardhika, G. (2014). 4G Handbook Edisi Bahasa Indonesia (Edisi Pert, Vol. 1).

[2] Rahmaddian, Y., \& Huda, Y. (2020). Analisis Performansi Jaringan 4G LTE di Gedung ITL FT Unp Kampus Air Tawar Barat. VoteTEKNIKA: Jurnal Vocational Teknik Elektronika dan Informatika, 7(4), 40-48.

[3] Ariyani, S. (2016). Evaluasi Kwalitas Layanan (QOS) Jaringan Data Selluler Pada Teknologi 4G LTE. Jurnal Penelitian IPTEKS, 1(2).

[4] Efriyendro, R., \& Rahayu, Y. (2017). Analisa Perbandingan Kuat Sinyal 4G LTE Antara Operator Telkomsel dan XL AXIATA Berdasarkan Paramater Drive Test Menggunakan Software G-NetTrack Pro Di Area Jalan Protokol Panam (Doctoral dissertation, Riau University).

[5] Hastruman, P., Fahmi, A., \& Usman, U. K. (2020). Analisa Kinerja pada Perencanaan TD-LTE ADVANCED Studi Kasus Kota Bandung. AVITEC, 2(2), 75-90.

[6] Rahmat Gemilang, Y. U. S. U. F. (2016). Kendali Jarak Jauh UAV (Unmanned Aerial Vehicle) Tipe Quadcopter Menggunakan Transceiver Nrf24101+ Beserta Job Sheet Uji Coba. Jurnal Pendidikan Teknik Elektro, 5(3). 
[7] Usman, U. K., Prihatmoko, G., Hendraningrat, D. K., \& Purwanto, S. D. (2012). Fundamental Teknologi Seluler LTE. Bandung, Indonesia: Rekayasa Sains.

[8] Nursafitri, D. A., Usman, U. K., \& Maulana, M. I. (2020, July). Long Term Evolution (LTE) Network Planning in Jakarta-Cikampek Elevated Toll. In 2020 IEEE International Conference on Industry 4.0, Artificial Intelligence, and Communications Technology (IAICT) (pp. 146-150). IEEE.

[9] Dilaga, D. F. S., Usman, U. K., \& Perdana, D. (2019, November). Evaluation of Listen Before Talk (LBT) mechanism fairness at LTE-Licensed Assisted Access (LAA) against Wi-Fi 5 GHz. In Journal of Physics: Conference Series (Vol. 1367, No. 1, p. 012059). IOP Publishing.

[10] Putri, K. S. H., \& Usman, U. K. (2019, November). Analysis of Vehicle to Vehicle Communication Parameter on 5G Network. In 2019 Symposium on Future Telecommunication Technologies (SOFTT) (Vol. 1, pp. 1-6). IEEE. 